\title{
ADMINISTRASI KEUANGAN DALAM PENDIDIKAN
}

\author{
Nilda Miftahul Janna ${ }^{1}$, Aryanti $^{2}$, Adinda Dwikurnia ${ }^{3}$, Muhammad Arsyam ${ }^{4}$ \\ ${ }^{1}$ Sekolah Tinggi Agama Islam (STAI) Darul Dakwah Wal-Irsyad (DDI) Kota Makassar, Indonesia \\ Email: nildamiftahuljanna@gmail.com \\ ${ }^{2}$ Sekolah Tinggi Agama Islam (STAI) Darul Dakwah Wal-Irsyad (DDI) Kota Makassar, Indonesia \\ Email: aryantialfi223@gmail.com \\ ${ }^{3}$ Sekolah Tinggi Agama Islam (STAI) Darul Dakwah Wal-Irsyad (DDI) Kota Makassar, Indonesia \\ Email: adindadwikurnia88@gmail.com \\ ${ }^{4}$ Sekolah Tinggi Agama Islam (STAI) Darul Dakwah Wal-Irsyad (DDI) Kota Makassar, Indonesia \\ Email: arsyam0505@gmail.com
}

\begin{abstract}
ABSTRAK
Kualitas sebuah negara dapat dilihat dari beberapa faktor salah satunya ialah pendidikan. Dalam pendidikan ini perlu adanya pembiayaan, pembiayaan ini agar lebih mudah perlu adanya administrasi keuangan. Dalam administrasi keuangan perlu adanya seorang bendahara yang bertugas mencatat pemasukan dan pengeluaran. Tujuan penulisan artikel ini adalah untuk mengetahui pengertian dari administrasi keuangan, sumber dana keuangan pendidikan, jenis-jenis pengeluaran, pengelola keuangan sekolah, proses administrasi keuangan dan peran guru dalam administrasi keuangan sekolah.
\end{abstract}

\section{A. PENDAhULUAN}

Dalam penyeleggaraan pendidikan, keuangan dan pembiayaan merupakan potensi yang sangat menentukan dan merupakan bagian yang tak terpisahkan dalam kajian administrasi dan manajemen pendidikan. Komponen pembiayaan dan keuangan pada tingat satuan pendidikan merupakan komponen produksi yang menentukan proses terlaksananya kegiatan-kegiatan proses belajar-mengajar di sekolah bersama komponenkomponen lain. Dengan kata lain, setiap kegiatan yang dilakukan sekolah memerlukan biaya, baik disadari maupun tidak.

Komponen keuangan dan pembiayaan ini perlu dikelola sebaik-baiknya agar dana yang ada dapat dimanfaatkan secara optimal untuk menunjang tercapainya tujuan pendidikan. Hal ini penting, terutama dalam rangka implementasi Manajemen Berbasis Sekolah, yang memberikan kewenangan sekolah untuk mencari dan memanfaatkan berbagai sumber dana sesuai dengan keperluan sekolah. Disebabkan pada umumnya dunia pendidikan selalu dihadapkan pada masalah keterbatasan dana. Apalagi dalam berbagai kondisi perekonomian dunia yang sedang dilanda krisis.

Berdasarkan pemikiran di atas, pengelolaan keuangan pendidikan lebih difokuskan dalam proses merencanakan alokasi secara teliti dan penuh perhitungan serta mengawasi pelaksanaan dana, baik biaya operasional maupun biaya kapital, disertai bukti-bukti secara administratif dan fisik (material) sesuai dengan dana yang dikeluarkan. Oleh karena itu, dalam artikel ini akan dipaparkan beberapa penjelasan mengenai administrasi keuangan. 


\section{B. PEMBAHASAN}

\section{Pengertian Administrasi Keuangan}

Administrasi keuangan sekolah adalah langkah pengolahan keuangan sekolah mulai dari penerimaan sampai dengan bagaimana mempertanggungjawabkan keuangan yang digunakan secara obyektif dan sistematis. Langkah tersebut sangat penting sekali diperhatikan, karena masalah pembiayaan adalah menjadi sarana vital bagi mati hidupnya suatu organisasi sekolah.

Selain itu Mulyono, MA. berpendapat bahwa administrasi keuangan sekolah adalah seluruh proses kegiatan yang direncanakan dan dilaksanakan atau diusahakan secara sengaja dan sungguh-sungguh, serta pembinaan secara kontinu terhadap biaya operasional sekolah sehingga kegiatan pendidikan lebih efektif dan efisien serta membantu pencapaian tujuan pendidikan.

Unsur biaya adalah hal yang menentukan dalam mekanisme penganggaran. Penentu biaya sangat mempengaruhi tingkat efektivitas dan efisiensi lembaga atau organisasi dalam mencapai tujuan tertentu. Kegiatan yang dilaksanakan dengan biaya yang rendah dan hasilnya mempunyai kualitas yang baik, maka kegiatan tersebut dapat dikatakan sebagai kegiatan yang dilaksanakan secara efektif dan efisien.

Dari beberapa pengertian di atas dapat disimpulkan bahwa administrasi keuangan adalah sebuah analisis terhadap sumber-sumber pendapatan dan penggunaan biaya (expenditure) yang diperuntukkan sebagai pengelolaan pendidikan secara efektif dan efisien dalam rangka mencapai tujuan yang telah ditentukan.

\section{Sumber Keuangan Pendidikan}

Adapun Sumber dana keuangan dan pembiayaan pada suatu lembaga pendidikan atau sekolah secara garis besar dapat dikelompokan atas 4 sumber, yaitu :

\section{1) Dana dari Pemerintah}

Dana dari pemerinatah disediakan melalui jalur Anggaran Rutin dalam Daftar Isian Kegiatan (DIK) yang dialokasikan kepada semua sekolah, dan ini biasanya disebut dana rutin. Besarnya dana yang dialokasikan dalam DIK biasanya dialokasikan berdasarkan jumlah dari peserta didiknya. Maka, besarnya anggaran dan besarnya dana untuk masing-masing jenis pengeluaran sudah ditentukan oleh pemerintah di dalam DIK. Pengeluaran dan pertanggungjawaban atas pemanfaatan dana rutin DIK harus benarbenar sesuai dengan mata anggar tersebut. Selain DIK, pemerintah sekarang juga memberikan Bantuan Operasional Sekolah (BOS). Dana ini diberikan secara berkala yang digunakan untuk membiayai seluruh kegiatan operasional sekolah.

\section{2) Dana dari Orang tua Siswa}

Dana ini di kenal dengan istilah iuran komite. Besarnya sumbangan yang harus dibayar orang tua siswa ditentukan oleh rapat komite sekolah. Pada umumnya dana komite sekolah terdiri dari yaitu dana tetap bulan sebagai uang kontribusi yang harus dibayar oleh orang tua setiap bulan selama anaknya menjadi siswa disekolah tersebut, dana incidental yang dibebankan kepada siswa baru yang biasanya hanya satu kali selama tiga tahun tahun, dana sukarela yang biasanya ditawarkan kepada orang tua siswa tertentu yang dermawan dan bersedia memberikan sumbangannya secara sukarela tanpa suatu ikatan apapun. 


\section{3) Dana dari Masyarakat}

Dana ini merupakan sumbangan sukarela yang tidak mengikat dari angota- anggota masyarakat sekolah yang menaruh perhatian terhadap kegiatan pendidikan disuatu sekolah. Sumbangan sukarela yaang diberikan merupakan wujud dari kepeduliannya yang merasa terpanggil untuk membantu memajukan pendidikan. Dana ini biasanya diterima dari perorangan, organisasi, yayasan, ataupun dari pemerintah dan swasta.

4) Dana dari Alumni

Dana ini biasanya digunakan untuk membantu meningkatkan mutu sekolah, misalnya seperti buku-buku, alat dan perlengkapan belajar.

\section{Jenis-Jenis Pengeluaran}

Dimensi alokasi secara garis besar digolongakan kedalam dua jenis pengeluaran, yaitu pengeluaran rutin yang sifatnya berulang (recurrent expenditure) atau aktiva lancar dan pengeluaran kapital atau modal (capital expenditure) atau aktiva tetap. Pengeluaran rutin atau berulang adalah biaya yang digunakan secara berkala dalam suatu masa tertentu (bulanan atau tahunan) seperti gaji guru, gaji pengelola, upah pegawai, pembelian bahan-bahan ATK, biaya pemeliharaan gedung, halaman sekolah, dan dana-dana operasional. Dana yang dipergunakan dalam kegiatan rutin ini memerlukan pengelolaan yang baik, terutama bagi lembaga pendidikan swasta (swadana) atau tidak terdapat bantuan pemerintah.

Untuk ini perlu dikuasai prinsip-prinsip pengelolaan kas, pengelolaan utang, dan pengelolaan barang atau fasilitas. Pengelolaan kas terutama menyangkut hal-hal yaitu penentuan jumlah uang tunai kas yang diperlukan agar tidak berlebihan dan juga tidak terlampau kecil, pengendalian aliran-aliran uang tunai, baik yang masuk kesekolah maupun yang dikeluarkan oleh sekolah. Sedangkan pengelolaan utang menyangkut syarat-syarat dan sanksi-sanksi yang dikenakan jika meminjam dana dari pihak luar baik jangka panjang ataupun janka pendek. Dalam hal ini perlu diperhitungkan masak-masak berapa jumlah uang yang layak atau rasional untuk di inventarisasikan dalam pendidikan. Demikian pula dengan biaya modal atau aktiva tetap yang dipergunakan untuk mendirikan bangunan sekolah, pembelian tanah, sarana pendidikan lainnnya, kantin, poliklinik (balai pengobatan umum), sarana olah raga (sport hall) yang relatif besar, memerlukan pengelolaan dengan baik.

\section{Pengelola Keuangan Sekolah}

Pengelola keuangan adalah orang yang bertugas untuk mengelola keuangan sekolah. Orang tersebut kita kenal dengan bendahara. Bendahara disini mempunyai tugas yaitu memegang buku kas umum, pemegang buku kas pembantu anggaran, buku bank, buku pajak registrasi SPM, membuat laporan dan arsip laporan keuangan.

\section{Proses Administrasi Keuangan}

\section{1) Perencanaan (RPS, RKAS)}

Perencanaan sekolah adalah suatu proses untuk menentukan tindakan untuk menentukan masa depan sekolah yang tepat melalui urutan pemilihan, dengan memperhitungkan sumberdaya yang tersedia. RPS adalah gambaran tentang kegiatan sekolah dimasa depan dalam rangka untuk mencapai tujuan sekolah yang telah ditetapkan. 
Rancangan Pengembangan sekolah (RPS) merupakan salah satu wujud dari manajemen sekolah yang sangat penting yang harus di miliki sekolah sebagai panduan dalam menyelenggarakan pendidikan sekolah baik dalam jangka panjang, menengah, maupun jangka pendek. RPS disusun untuk :

a) Menjamin agar perubahan atau tujuan sekolah yang ditetapkan dapat dicapai dengan tingkat kepastian yang tinggi dan resiko yang kecil,

b) Mendukung kordinasi antar pelaku sekolah,

c) Menjamin terciptanya integrasi, sinkronisasi, dan sinergi baik antar pelaku sekolah, antar sekolah, dan dinas pendidikan kabupaten atau kota dan antar waktu.

Rencana anggaran pendapatan dan belanja sekolah (RAPBS) pada dasarnya memuat tentang berbagai program dan kegiatan yang akan di laksanakan sekolah selama 1 kegiatan yang akan dilaksanakan sekolah, keuangan untuk membiayai program tersebut selama 1 tahun anggaran. Penyusunan RAPBS dapat menempuh beberapa langkah yaitu sebagai berikut :

$\checkmark \quad$ Penetapan Tujuan, merupakan suatu keharusan dalam penyusunan anggaran yang efektif.

$\checkmark \quad$ Penjabaran tujuan kedalam program pendidikan.

$\checkmark$ Penentuan sumber daya manusia dan materil yang beriplementasikan program-program pendidikan yang ditetapkan.

Adapun pengeluaran biaya sekolah meliputi aspek sebagai berikut :

- Pengawasan umum

- Pengajaran

- Pelayanan bantuan

- Pemeliharaan gedung

- Operasi

- Pengeluaran tetap dan jasa hutang

RKAS harus disetujui dalam rapat dewan pendidik setelah memperhatikan pertimbangan dari komite sekolah dan disahkan oleh Dinas Pendidikan kabupaten atau kota (untuk sekolah negri) atau yayasan (untuk sekolah swasta). Secara rinci diatur dalam peraturan Mendiknas Nomor 19 tahun 2017 tentang Standar pengelolaan Pendidikan oleh Satuan Pendididkan Dasar dan Menengah.

\section{2) Pelaksanaan (Penggunaan, Pencatatan Dana)}

Departemen Dalam Negri (Depdagri) dan Departemen Pendidikan dan Kebudayaan (Depdikbud) 1996 menyatakan bahwa dalam administrasi keuangan harus ada pemisahan tugas dan fungsi otorisator, ordonator dan perbendaharaaan. Otorisator adalah pejabat yang diberi wewenang untuk mengambil tindakan yang mengakibatkan terjadinya penerimaan atau pengeluaran keuangan. Ordonator adalah pejabat yang berwenang yang melakukan pengujian dan memerintahkan pembayaran atas segala tindakan yang dilakukan berdasarkan otorisasi yang telah ditetapkan. Bendaharawan adalah pejabat yang berwenang yang melakukan penerimaan dan pengeluaran uang atau surat-surat berharga lainnya, yang dapat dinilai dengan uang dan di wajibkan membuat perhitungan dan pertanggung jawaban.

Penggunaan uang mestinya sesuai dengan alokasi anggaran yang sudah ditetapkan sebelumnya. Oleh karena itu pengaturan penggunaan dan pembukuan keuangan tidak dapat dilakukan oleh sembarang orang dan semuanya harus melalui proses dan prosedur yang berlaku. 


\section{3) Pelapor dan Pertanggungjawaban}

Penerimaan dan pengeluaran sekolah harus di laporkan dan dipertanggung jawabkan secara rutin sesuai peraturan yang berlaku. Pelaporan dan pertanggung jawaban anggaran rutin dan pembangunan dilakukan dengan memperhatikan ketentuan yang telah disepakati yaitu sebagai berikut :

> Selambat-lambatnya tanggal 10 setiap bulan, bendaharawan mengirim Surat Pertanggung Jawaban (SPJ) kepada walikota atau bupati melalui bagian Keuangan Sekretariat Daerah

> Apabila tanggal 10 bulan berikutnya SPJ belum diterima oleh Bagian Keuangan Sekretariat Daerah maka tanggal 11 dikirimkan Surat Peringatan I.

$>$ Apabila sampai dengan tanggal 20 bulan berikutnya SPJ belum dikirim juga kebagian Keuangan Sekretariat Daerah, maka dibuatkan Surat Peringatan II.

$>$ Kelengkapan lampiran SPJ

$>$ Bukti Pendukung atau Lampiran SPJ

\section{Peran Guru Dalam Administrasi Keuangan Sekolah}

Penanggung jawab biaya pendidikan adalah kepala sekolah namun demikian, guru diharapkan ikut berperan dalam administrasi biaya ini meskipun menambah beban mereka, juga memberikan kesempatan untuk ikut serta mengarahkan pembiayaan itu untuk perbaikan proses belajar mengajar. Administrasi keuangan meliputi kegiatan perencanaan, penggunaan, pencatatan data, pelaporan dan pertanggung jawaban dana yang dialokasikan untuk penyelenggaraan sekolah. Tujuan administrasi ini adalah untuk mewujudkan suatu tertib administrasi keuangan, sehingga pengurusannya dapat di pertanggungjawabkan sesuai dengan ketentuan yang berlaku.

Adapun Beberapa peran guru dalam administrasi keuangan sebagai berikut :

$\checkmark$ Membuat file keuangan sesuai dengan dana pembangunan.

$\checkmark$ Membuat laporan data usulan pembayaran gaji, rapel ke Pemerintah Kota.

$\checkmark$ Membuat pembukuan penerimaan dan penggunaan dana pembangunan.

$\checkmark$ Membuat laporan dana pembangunan pada akhir tahun anggaran.

$\checkmark$ Membuat laporan Rancangan Anggaran Pendapatan Bantuan Sekolah (RAPBS).

$\checkmark$ Membuat laporan tribulan dana Bantuan Operasional Sekolah (BOS).

$\checkmark$ Menyetorkan pajak PPN dan PPH.

$\checkmark$ Membagikan gaji atau rapel.

$\checkmark$ Menyimpan dan membuat arsip peraturan keuangan sekolah.

\section{PENUTUP}

\section{Kesimpulan}

Administrasi keuangan adalah semua aktivitas yang berhubungan dengan keuangan yang mencatat pemasukan dan pengeluaran yang dicatat oleh seorang bendahara. Keuangan sekolah ini bisa bersumber dari pemerintah, orang tua siswa, masyarakat maupun dari alumni. Setiap administrasi keuangan sekolah dilakukan sesuai dengan proses yang telah ditentukan. Dalam administrasi keuangan sekolah ini, guru memiliki peran yang sangat penting. 
2. Saran

Berdasarkan kesimpulan diatas, maka penulis memberi saran kepada sekolah- sekolah agar administrasi keuangan dilakukan secara transparan tanpa menyembunyikan apapun, sehingga administrasi keuangan bisa berjalan dengan baik.

\section{DAFTAR PUSTAKA}

Arsyam, M. (2021). BAHAN AJAR ADMINISTRASI PENDIDIKAN. [10/1 15.20]

Ruwindika, A. F. G. (2019). Administrasi Keuangan Dalam Dunia Pendidikan.

Arsyam, M. (2020). Manajemen pendidikan islam. [10/1 15.19]

Salsabilafitri, Nadya, and Hade Afriansyah. "Administrasi Keuangan." (2019).

Arsyam, M., \& Alwi, A. M. (2020). MANAJEMEN HIDUP DALAM PERSPEKTIF AL-QUR'AN. [10/1 15.20]

Afriansyah, Hade. "Administrasi Keuangan." (2019).

Ahmad, H., \& Arsyam, M. (2020). ETIKA PERDAGANGAN DALAM ISLAM.

Makmur, Z., Arsyam, M., \& Alwi, A. M. S. (2020). Strategi Komunikasi Pembelajaran Di Rumah Dalam Lingkungan Keluarga Masa Pandemi. KOMUNIDA : Media Komunikasi dan Dakwah, 10(02), 231-241. 